\title{
Improving Students' Writing Skills through the Application of Synectic Model of Teaching Using Audiovisual Media
}

\author{
${ }^{1}$ Ufi Ruhama', ${ }^{2}$ Dewi Ismu Purwaningsih \\ ${ }^{1}$ Universitas Muhammadiyah Pontianak \\ ${ }^{2}$ Universitas Nahdlatul Ulama Kalimantan Barat \\ ufiruhama@unmuhpnk.ac.id
}

\begin{abstract}
Writing might be difficult for some people (Alwasilah, 2007). Some students can speak English fluently and confidently, although since they have difficulties in conveying their ideas in writing. Thus, it needs the effective and efficient model of teaching to improve the teaching learning process. Synectic model of teaching is a model applied to enhance students' ability to write. This model combines various forms of metaphoric thinking to see old ideas in different ways. In this research, the researcher used audiovisual media to support learning. The purpose of this research is to find out students' improvement in writing descriptive texts using synectic model of teaching. The sample of the research was 36 students of class IXD in MTsN 2 Pontianak. The research was Classroom Action Research using Kemmis and MC Taggart model with two cycles. The result shows that there is improvement in students writing skill. The mean score of pre-test is 56.01, posttest 1 is 66.5 , and posttest 2 is 87.46 . It means the application of synectic model of teaching using audiovisual media is able to increase students' ability in writing descriptive text.
\end{abstract}

Keywords: writing skill, descriptive text, synectic model, audiovisual

How to Cite: Ruhama, U., Purwaningsih, D.I. (2018). Improving student's writing skills through the application of synectic model of teaching using audiovisual media. English Language Teaching Educational Journal, 1(3), 176-190.

\section{INTRODUCTION}

\section{Background}

It cannot be denied that writing is the complex skills because the students need to comprehend spellings, grammars, sentences, vocabularies, and structures as the units in writing. Wasilah (2009) said that writing is considered difficult and people will be able to write after they have mastered listening, speaking, and reading skill. Writing not only gets the words down, but it also needs the skills to choose the words, spelling, punctuations, grammar, sentence linking, and text construction correctly (Phillip, 2003).

Based on pre-observation in the class, the teacher taught students in monotonous ways, so the students were less motivated in learning. It caused the 
students not interested in learning. The writing skill of the students in class IXD of Islamic Junior High School (MTs) N 2 Pontianak was in low category of proficiency. They could not convey their ideas clearly in writing because they had limited vocabularies, low proficiency, and were less motivated in learning English. These factors made them difficult to express their ideas through writing.

Writing is not just about a skill, but it is more than how the writers can encourage or extend their thinking, ideas, and motivate themselves to communicate with other people through writing (Fulwiller,2002). Moreover, writing makes our thoughts visible, changing our thinking into print, allowing us to develop and encourage our ideas (Harmer, 2007).

Writing as a complex skill needs a process to be mastered. Some students can speak English well and fluently, but they find it difficult to convey their ideas in writing. It requires interesting methods in teaching to change students' mindset in learning, such as making new habits of students in learning. The effective and efficient learning model can motivate the teacher to create and apply the creative technique in class, therefore, learning writing can be one of the interesting skills to be learnt.

Writing can be learnt in various models (Wagiran and Doyin, 2005).One of them is writing an essay. The students are supposed to develop not only their ideas in making an essay, but also strategies to express their ideas, and making the interesting essay to be read. They have to arrange and connect their sentences to be a complete essay.

The effective teaching is based on the process of teaching learning itself, such as students learn easily, pleasantly, and learning objectives are achieved. Nowadays, the teaching learning process still tends to be teacher-centered, thus it makes the students passive and unable to express their ideas in the class that affected their score (Agustina, 2016). Learning English at school is mostly boring. English has not been taught using innovative methods. Teachers have not used the teaching media in class (Prasmono, 2010). On the other hand, curriculum 2013 demands the students to be active and the teachers to be the facilitator in the process of teaching learning. During the process of writing, the teacher can be the facilitator, guide, and motivator (Brown, 2001 and Harmer, 2001).

People who love reading cannot be guaranteed that they can write well. The theory that states that a good reader would be a good writer is a myth because many people who love reading cannot write well (Pudewa, 2011). Indeed, people who have learning style can be a good writer because the ability to write belongs to all people. Anyone who is motivated to learn and always practice writing seriously will be able to write well (Schneider, 2011). Vivanco stated that the ability to write has nothing to do with the innate nature but related to motivation and attitudes (Vivanco, 2009). 
State Islamic Junior High School 2 (MTsN 2) Pontianak is one of the favorite schools in Pontianak. As the favorite school, it demands the students to have good English proficiency. It interests the writer to do the research in this area by applying Synectic model of teaching.

Writing can be learnt in various forms (Wagiran and Doyin, 2005). One of them is writing descriptive text. In writing, students are expected not only to be able to develop the ability to make an essay, but also expected to express ideas by making interesting essays to read. They have to arrange and connect their sentences to be a complete essay. One learning model that can be applied in improving students' writing skills is synectic model of teaching. Synectic was from Greek, it means combining the different forms. According to Gordon (1980) synectics is a combination of several forms using figures of speech to obtain new views. Therefore, the synectic model of teaching is a learning model which brings together several elements by using figures of speech to get new views. The figure of speech in the questionnaire is a metaphorical activity.

Synectic model of teaching is a creative model of teaching. It focuses on the students' creativity and students' strategy to solve the problem using rational and intellectual way with rational and emotional way. This model was designed by Gordon and aimed to develop students' creativity (Aunurrohman:2014). Synectic process involves the implementation of metaphor, that is the comparison between two objects, ideas or concepts. (Estes et al., 2010).

Most students had difficulties in choosing the main idea when they wrote a descriptive text. Even after they have been explained about the main idea, they still had difficulties in developing and exploring their ideas. Furthermore, they had the negative perception about writing, i.e. writing was complex and difficult skill to be mastered. Therefore, the synthetic model of teaching is used to enhance students' writing competency.

In this research, the writer took audiovisual media to implement the synectic model to transfer the knowledge. .The use of learning model in the learning process could facilitate the accomplishment of the learning objectives. Learning media are a vehicle and delivery of information or learning messages to students. By using media during learning, the media can help teachers to improve the student achievement (Sari and Sasongko, 2013). Dunifa (2016) stated that it cannot be guaranteed that anyone who is diligent in reading will be able to write. The theory that states that a good reader would be a good writer is a myth because many people who love reading cannot write well (Pudewa, 2011). Indeed, people who have learning style can be a good writer because the ability to write belongs to all people. Anyone who is motivated to learn and always practices writing seriously will be able to write well (Schneider, 2011). Vivanco stated that the ability to write has nothing to do with the innate nature but related to motivation and attitudes (Vivanco, 2009). 
According to Wahyuningsih et al (2014), audiovisual learning media are one of the media that enable two senses of the students, namely sensory and auditory so they can improve student learning and achievement. Furthermore, the audiovisual media are used to make the students more interested, especially when the students were offered with several films which were short duration, have good stories, and contained the simple language to be understood, so the media are able to attract students' interest in understanding the subject matter.

Synectic model of teaching using audiovisual is an interesting method because it provides the students to explore and experience. It creates the variety of writing because it gives the students many ideas to be written. This model has strengths, It develops the creative thinking of the students and teacher and helps the students to solve the problem. On the other hand, this model has weaknesses, it is difficult to be applied to the class with the oldest methods of teaching and class which does not have adequate facilities (Mutmainah, Aquami, 2016).

\section{Teaching Writing Descriptive Text}

According to Wagiran and Doyin (2005), writing is a language skill used for communicating indirectly. This skill is obtained through the process of learning and practicing. Writing is also a complicated process, such as prewriting, observing, drafting, revising, and the last is editing. It requires the ability to communicate ideas, opinions, and feelings in writing.

This research focuses on descriptive text writing. It is related to characteristics, people, or things in a basic way. Kane (2000) said that description is about something that can be looked, can be heard and can be tested.

These are the steps in writing descriptive text (Muchlisoh, 1994):

1. Formulating the objective of the writes in writing;

2. Observing the object carefully;

3. Making the details about what was the writer seen, heard, and felt about the object, especially the object related to the purpose of writing; and

4. Giving the additional explanation to give the special things in writing.

\section{Synectic Model of Teaching Using Audiovisual Media}

According to Joice, et. al, there are two strategies or models in teaching as the basic of synectic model of teaching, i.e. creating something new and making the strange things become familiar. It can be seen as follows.

1. The first strategy (creating something new).

a. First stage: the teacher asks students to describe the situation and topic.

b. The second step: students make their own direct analogies, choose them, explore them further.

c. The third step: students become their imagining object as they have chosen in the second stage. 
d. The fourth step: Students take descriptions of the second and third stages, proposing some analogies conflict and choosing one of them.

e. The fifth step: students make and take their other own direct analogy, that is based on the conflict of analogy.

f. The last step: the teacher asks students to do the task and uses the last of analogy or their syntactic experience.

2. The second strategy (making the strange things become familiar).

a. The first step: the teacher provides information about the new topics.

b. The second step: the teacher proposes a direct analogy and students describe it.

c. The third step: the teacher asks students to "be" a direct analogy.

d. The fourth step: students identify and elaborate the points of similarity between new topic and direct analogy.

e. The fifth step: students elaborate wherever the analogies are not appropriate.

f. Sixth step: Students explain the original topic.

g. Stage step: Students prepare a direct analogy and explore similarities and differences

In this research, audiovisual media were used to implement the learning model of teaching. Learning media are an intermediary tool that can help the process of teaching and learning which aim to clarify the meaning from the message delivered to make the purpose better and perfect (Pulukadang, 2016).Sanjaya (2006) in Pulukadang (2016) states that audio visual media contain the sound and picture that can be seen, for example the video recordings in various sizes of movies, sound slides and etc. Using visualization in giving the material can build students interest in learning, thus the students will have more motivation in learning. They also make the teaching learning process easily and pleasantly so the students' achievement will get increased.The use of audiovisual as the media of teaching in this research aims to improve the score of writing.

\section{RESEARCH METHOD}

This research used Kemmis and McTaggart'smodel of Classroom Action Researh. This classroom action research focused on efforts to change the real conditions happening to the expected conditions (improvement oriented).The research used two cycles that each cycle consisted of 4 stages, namely planning, implementation, observation, and reflection. The methods consisted of:

1. Planning

The teacher and collaborator (researcher) prepared the process of teaching learning, as follows:

a. Preparing teaching media and constructing some steps in doing the action. The writer as the collaborator assisted the teacher in designing each cycle in four meetings.

b. Making the lesson plan which was implemented in teaching learning process. 
c. Designing students' test.

d. Designing observation sheet.

2. Acting

In this level, the teacher implemented the planning, i.e. Teaching writing description text. The theme in this meeting was based on the textbook. The teaching was done in four meetings divided into two cycles. The teaching learning process used the synectic model of teaching with audiovisual media.

3. Observing

In this level, observation systematically in the classroom was conducted by the researcher. The observation was done by the observer when the teacher learning process took place to see the process occurring during the action, the impact of using the method, and the problem occurring in the process of teaching learning. This level was conducted to collect the data to improve the next process.

4. Reflecting

In this level, the writer reflected the impact of implemented method then evaluated the process of teaching learning. It was used to improve for the learning and teaching process in the next cycle.

Action research model was described as spiral steps by Kemmis and McTaggart in Burns (2010) as follows:

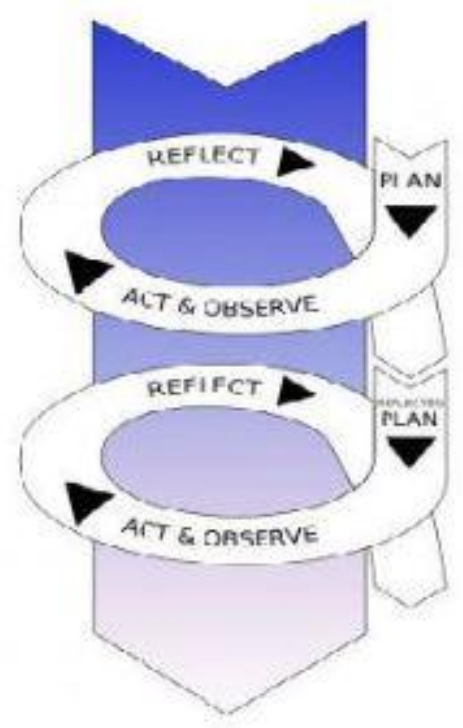

Figure 1. Spiral of Classroom Action Research

The research was held in MTsN 2 Pontianak. It involved class IX D, there were 36 students. The data collecting techniques in this research namely 
observation, interview, and test. The researcher conducted the observation in the class while the teaching learning process was being done. The researcher observed the interaction of the students and all activities in the classroom. The collecting data used field notes as the tool.

The interview was done in the pre-research to the English teacher. The interviewed aimed to find out the problems faced by the students in writing. Furthermore, the test was given to the students to know the improvement of students particularly in writing. It consisted of pre-test and post-test of the last session. The pre-test was given before the method was implemented. The posttest was conducted to know the progress students' writing ability of descriptive text. In conclusion, the tests aimed to measure the improvement writing skill of students. Qualitative and quantitative were used in analyzing the data. The qualitative was analyzed from the data in observation. Quantitative data were gained from the test. It was analyzed to find out the writing skill improvement from the test and both cycle 1 and 2 tests. The improvement was seen from the mean score of the results.

The writing evaluation used the analytic method by Reid (1993). It elaborated the writing product into five elements, namely content, form/organization, vocabulary/style, language use/grammar, and mechanics. The categorization of students writing skills can be seen in Table 1.

Table 1. The Category of the Students' Writing Skills

\begin{tabular}{ll}
\hline Score & Categorization \\
\hline $89-100$ & Excellent \\
$79-88$ & Good \\
$66-78$ & Fair \\
$46-65$ & Poor \\
$0-45$ & Very Poor \\
\hline
\end{tabular}

\section{RESULTS AND DISCUSSION}

The result was taken from the teaching learning process during the research. It was implemented in two cycles. In each cycle, the students were given the test to know their improvement in descriptive writing text using audiovisual media in the synectic model of teaching.

The research implementation was conducted collaboratively with the English teacher of MTsN 2 Pontianak. Before implementing the synectic model of teaching, the researcher had interviewed the students about their difficulties in learning English. From the student's 'interview, it can be concluded that the they faced the difficulties in writing. They had difficulties in conveying their ideas, selecting the appropriate words, and organizing their ideas in writing. 
Before the action, the writer had conducted pre-test to know the students' ability of writing. From the test, it can be known that the mean score of students was 56.01. It was categorized as poor. There were 3 students who had high score, 12 students that had medium score and 21 students that had low score in descriptive text writing. The students had difficulties in using the appropriate words or correct grammatical forms. They also had the limited vocabularies. They also found difficulties in making good paragraphs and using the correct punctuations.

The questionnaires were delivered in the end of pre-test. It was used to know the attitude of the students toward the teaching learning process in the classroom.

Table 2. Students' Attitude of Teaching Learning Process before Applying Synectic Model of Teaching

\begin{tabular}{|c|c|c|c|}
\hline \multirow[t]{2}{*}{ No } & \multirow[t]{2}{*}{ Questions Items } & \multicolumn{2}{|c|}{$\begin{array}{r}\text { Students } \\
\text { Answer }\end{array}$} \\
\hline & & Yes & No \\
\hline 1 & Do you like English? & 30 & 6 \\
\hline 2 & Do you like English writing? & 20 & 16 \\
\hline 3 & Do you think that writing descriptive is difficult? & 28 & 8 \\
\hline 4 & Do you feel bored while studying English? & 28 & 8 \\
\hline 5 & Do you enjoy studying by using video/film? & 32 & 4 \\
\hline 6 & Do you always learn English using media? & 21 & 15 \\
\hline 7 & $\begin{array}{l}\text { Are you willing to learn descriptive text by using } \\
\text { audiovisual media? }\end{array}$ & 33 & 3 \\
\hline 8 & $\begin{array}{l}\text { Do you agree if learning by watching video is } \\
\text { interesting? }\end{array}$ & 29 & 6 \\
\hline 9 & $\begin{array}{l}\text { Do you think that using media in learning can } \\
\text { motivate you to study? }\end{array}$ & 28 & 8 \\
\hline
\end{tabular}

Based on the problems above, the researcher applied synectic model of teaching using audiovisual media to enhance the students writing skill.

\section{Cycle 1}

The activities as follows:

a. Planning

Before doing the research, the researcher had prepared the instrument based on the syllabus and had discussed with the teacher, such as:

1) Arranging the lesson plan and composing the step in doing the action.

2) Preparing the material and students worksheets and tests.

3) Preparing the notes to write and the video recorder to record the activities in the process of teaching and learning. 
b. Acting

The researcher was the collaborator who helped the teacher through the teaching and learning in the class.

1) The first cycle

a) The early meeting

(1) Opening

The teacher greeted the students in the class and asked some questions as the brainstorming. The questions were about the pre knowledge of the students in describing something. The researcher gave the conclusions based on the students answer.

(2) Main activity

In this stage, the teacher implemented the method. The teacher used videos and images that could attract the students' attention.The teacher explained about describing an object. Then, teacher played a video and asked students to describe the situation or topic they watched on the video. The students expressed a direct analogy, one was selected and developed. After that, students discussed and collaborated the conflicts in the video. Next, the teacher asked the students to review their discussion and put it in descriptive writing. Students were asked to read their writing in front of the classroom.

(3) Closing

The teacher reviewed the descriptive text characteristic and made a summary. The teacher asked the difficulties of writing descriptive text as well. Then, the teacher ended the class.

b) The second meeting

(1) Opening

The teacher greeted the students. Then, the teacher reviewed the material that was taught in the last meeting. He asked some questions to brainstorm them.

(2) Main activity

The teacher reviewed the previous material and the students still remembered about it. The teacher showed the video and let the students describe the people in the video. Afterwards, the teacher gave the test to complete paragraph related to the descriptive text. They were not allowed to ask their friends during the test.

(3) Closing

After the test had been submitted, the teacher asked the difficulties in doing the test. The teacher and students concluded the material. Then, the teacher ended the class.

c. Observing

The students' levels of interest in learning writing can be seen from the first cycle. The students participated actively in the process of teaching and learning. They answered the teacher's questions 
enthusiastically. Almost all the students paid attention to the explanation and cooperated well in the process of teaching and learning. The students found difficulties in writing the descriptive text, they lacked vocabularies and could not translate particular words. Besides, it was still hard for them in organizing the words to make them to be the sentences. Some sentences were grammatically incorrect. On the other side, the students participated actively in the class because the application of synectic model of teaching had motivated them in learning. They could also write the text longer than before.

\section{d. Reflecting}

The reflecting stage was done to evaluate the process of teaching learning in the first cycle. In this stage, both researcher and the teacher discussed some problems occurring in the class. It was found that the students still had lack of writing the descriptive text. They had difficulties in arranging the words and using the correct grammar. On the other hand, there was the improvement in the students' score compared to the one of the pre-test. The result showed that the students got 66.5 , which was categorized as fair. There were 7 students who had high score, 16 students who had the medium score and 13 students who had low score in writing descriptive text. To conclude, the students still needed the enhancement in their writing, thus it was needed to conduct the cycle 2 .

\section{Cycle 2}

The first cycle showed that there was enhancement in students' writing, however, there were still many difficulties faced by the students in writing descriptive text. Thus, the research continued to the cycle 2 conducted in two meetings.

a. Planning

In this stage, both researcher and teacher revised the plan in teaching. They reviewed the material and gave more attention to the structure of descriptive text that was the aim of descriptive text, the generic structure of the text, and the language feature of descriptive text. The teacher also taught the simple present tense because the students had difficulties in language use.

b. Acting

1) The first meeting

a) Opening

The teacher greeted and asked some questions to the students. After that, the teacher invited the students to describe their friends to recall their information about descriptive text.

b) Main activity

The teacher explained the descriptive text, such as the structure, the purpose, the generic structure; moreover, the 
language feature of descriptive text. After that, the teacher explained about simple present tense.

Students were asked to discuss and describe the building in the video. Students wrote a description text assisted by the researcher especially in vocabularies and structures. The students who have finished first were asked to write on the board while others read their friends' writing. The teacher asked students to observe their friends' writing and the teacher corrected. Then, the teacher asked the students' understanding by giving an ad-shaped video and then giving the questions and answering the students.

c) Closing

The researcher concluded the lesson that has been taught. After the question and answer session, the class ended.

2) The second meeting

In this session, the researcher gave the second post-test to the students to know the improvement of writing skills after applying the second cycle. The students did the test by themselves. They were not allowed to ask to their friends and look at their friends' writing.

c. Observing

In this cycle, there was improvement in students' participation. When the teacher conducted aperception, students showed their enthusiastic in answering questions. The teachers also provided motivation to make the students not feel hesitate and silly in asking and answering questions. Students participated actively in process of teaching learning because of the media used in the classroom.

According to the result of post-test 2, they were 34 students who had high score and 2 students had medium score. There were no students who had low score in writing descriptive text. The mean score of the students in writing descriptive text was 87.46.

d. Reflecting

In the cycle 2, it was found the improvement in students' writing skill and participation in the class.

The students were more motivated and interested in the process of teaching and learning. It can be seen from the observation in the teaching learning process. Furthermore, the analysis data on questionnaire showed that there was enhancement in the students' attitude toward the process of teaching learning in the class. It could be seen from Table 3. 
Table 3. The Result of the Second Questionnaire

\begin{tabular}{llll}
\hline No & \multicolumn{1}{c}{ Questions Items } & \multicolumn{2}{c}{$\begin{array}{c}\text { Students } \\
\text { Answer }\end{array}$} \\
& & Yes & No \\
\hline 1 & Do you like English? & 33 & 3 \\
2 & Do you like writing in English? & 27 & 9 \\
3 & Do you think that writing descriptive is difficult? & 31 & 5 \\
4 & Do you feel bored while studying English? & 33 & 3 \\
5 & Do you enjoy studying by using video/film? & 34 & 2 \\
6 & Do you always learn English using media? & 30 & 6 \\
7 & $\begin{array}{l}\text { Are you willing to learn descriptive text by using } \\
\text { audiovisual media? }\end{array}$ & 1 \\
8 & $\begin{array}{l}\text { Do you agree if learning by watching video is } \\
\text { interesting? }\end{array}$ & 33 & 3 \\
9 & $\begin{array}{l}\text { Do you think that using media in learning can } \\
\text { motivate you to study? }\end{array}$ & 24 \\
\hline
\end{tabular}

\section{Discussion}

The data collected from interview, observation and test show that there is improvement in students writing skills and attitudes toward learning English. At first, the researcher identified that the students had the low score in writing. The students faced the difficulties on it, such as the lack of vocabularies, the use of the correct grammar and punctuation, the use of the appropriate words, and the content of writing. They also had low motivation in writing because it was the most difficult skill to learn. Related to the problems, the researcher applied synectic model of teaching using audiovisual media.

1. The application of Synectic model of teaching using audiovisual

The teacher has applied the synectic model of teaching using audiovisual media to teach writing descriptive text to Class IX D students in MTsN2 Pontianak. This method is effective in teaching writing because the application of synectic model gives two effects, they are the effect of learning and co-effect (Djudin, 2017). It improves the general creative ability and creative ability of the students. As the result, it increases the students' ability in writing descriptive text.

2. The students' improvement in writing ability

From the analysis of students' mean score in writing descriptive text, it can be concluded that the application of synectic model of teaching using audiovisual can improve the students' ability in writing. It can be seen from their improvement in writing test. The improvements are the ability of choosing the correct words in vocabulary, making good sentences, making longer sentences, using the correct grammar and punctuation in the sentences. Besides, their regular writing practice had shown significant improvement in their writing result just as what Pratolo suggested in his study (2015). Their improvement in writing descriptive text can be seen in Figure 2. 


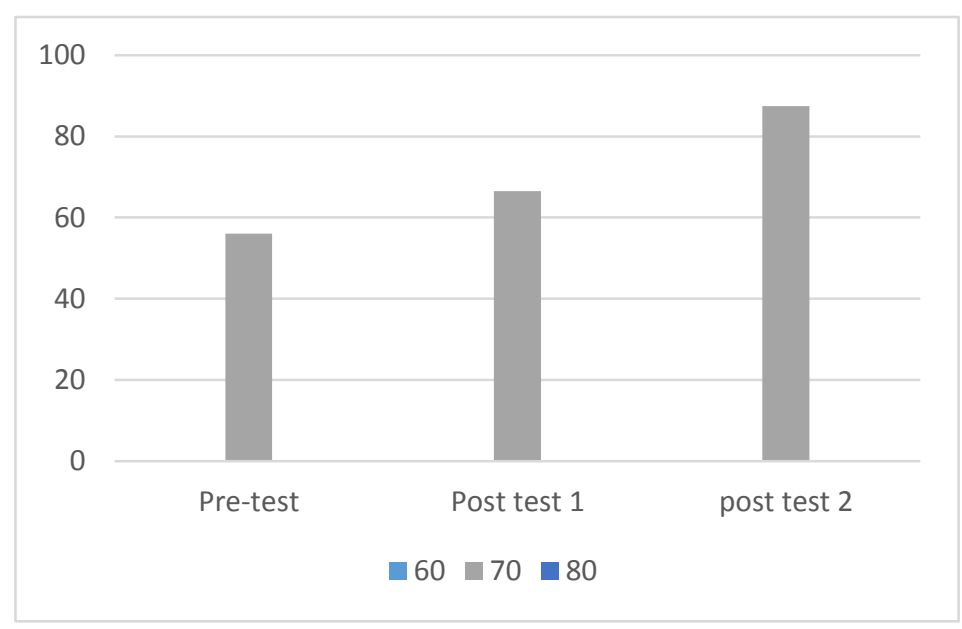

Figure 2. Students' Mean Score in Writing Descriptive Text Test

Based on Figure 2, it can be summarized that the students make the improvement in writing skill. The mean of pre-test is 56.01, post-test 1 is 66.5 , and post-test 2 is 87.46 . It means that the application of synectic model of teaching using audiovisual media can improve students' ability in writing descriptive text.

\section{CONCLUSION}

Based on several stages of the research that has been done, it can be concluded that the use of the synectic model of teaching in writing was very effective to increase the students' abilities in writing descriptive text. The implementation of this method helps the students in understanding and expressing their creative ideas in writing through the learning activities. This method not only makes students able to put creative ideas in writing but also help students be more motivated to learn and discuss groups and train them to participate actively in the process of learning.

The results of this study indicate that this method is very effective in improving students' writing in English. Therefore, it is expected that English subject teachers at MTsN2 Pontianak can apply this method in the process of teaching learning to make the students active in thinking, expressing their ideas and participating in class discussions, so it can create the fun teaching learning process. 


\section{REFERENCES}

Alwasilah, C. (2007). CTL menjadikan kegiatan belajar-mengajar mengasyikkan dan bermakna. Bandung: Mizan Learning Center.

Agustina, S., et. al, (2016). Pengaruh model pembelajaran sinektik terhadap hasil belajar fisik pada siswa kelas X SMA Negeri 4 Palu. Jurnal Pendidikan Fisika Tadulako (JPFT) Vol. 4 No. 2.

Aunurrahman. (2014). Belajar dan pembelajaran. Bandung: Alfabeta.

Brown, H. D. (2001). Teaching by principles. New York: Longman.

Burns, A. (2010). Doing action research in English language teaching. A guide for practitioners. London: Routledge Taylor \& Francis Group.

Dunifa,L. (2016). The effect of holistic and discrete tasks on english writing performance of students with different learning style. International Journal of English Language Teaching. Vol.4 No.9, pp1-13 November 2016.

Estes, T. H., Mintz, S. L. \& Gunter, M. A. (2010). Instruction: a models approach. London: Pearson.

Fulwiller. (2002). The Oxford essential guide to writing. New York.

Gordon, J.J. William. (1980). Synectics model. New York: Longman Publishers.

Harmer, J. (2001). The practice of English language teaching. Essex: Longman.

Harmer, J. (2007) How to teach writing. New York: Cambridge University Press.

Kane, T. (2000). The Oxford essential guide to writing. New York: Barkley Books.

Ruhama, Purwaningsih 
Prasmono, A. (2010). Pengaruh penggunaan media pembelajaran komputer multimedia dan digital video disc terhadap prestasi belajar listening ditinjau dari motivasi belajar siswa sekolah menengah pertama negeri di kabupaten Wonogiri. Tesis. Universitas Sebelas Maret Surakarta.

Pratolo, Bambang Widi (2017): Exploring Indonesian learners' beliefs about language learning strategies through reflection. figshare. Thesis. https://doi.org/10.4225/03/58b7763874bf3

https://monash.figshare.com/articles/Exploring_Indonesian_learners_b eliefs_about_language_learning_strategies_through_reflection/471192 $\underline{7}$

Pulukadang, W. T. (2016). Meningkatkan kosakata siswa melalui penggunaan media audio visual pada pelajaran bahasa inggris di kelas V SDN No. 30 Kota Selatan Kota Gorontalo. E-Jurnal Universitas Negeri Gorontalo.

Scheineider, P. (2011). Writing alone and with others. Oxford: Oxford University Press.

Djudin, T. 2017. Synectics Model: An offer to develop students' creativity through science learning. Journal of Education, Teaching, and Learning, 2 (1) : $65-70$.

Vivanco, V. (2009). Holistic versus communicative approach in assesing oral production in English, Relieve, Volume 15, Number 2.

Wagiran and Doyin, M. (2005). Curah Gagasan Pengantar Penulisan Karya Ilmiah. Semarang: Rumah Indonesia BIS FBS Unnes.

Wahyuningsih, M.G. S. (2014). Penerapan media audio visual dalam pembelajaran bahasa Inggris. Jurnal Teknologi Pendidikan dan Pembelajaran Vol.2, No.1, ,hal 79 - 92. 